\title{
Education and social networking: Between connectivism and the critical social philosophy of the new media*
}

\author{
M. De Martino' ${ }^{1}$, S. Kovalenko ${ }^{1}$, G. Tkach ${ }^{1}$, E. Isidori ${ }^{2}$ \\ ${ }^{1}$ RUDN University \\ Miklukho-Maklaya St., 6, Moscow, 117198, Russia \\ ${ }^{2}$ University of Rome Foro Italico \\ Piazza L. De Bosis 6, 00135, Rome, Italy \\ (email: de-martino-m@rudn.ru; kovalenko-sa@rudn.ru; \\ tkach-gf@rudn.ru; emanuele.isidori@uniroma4.it)
}

\begin{abstract}
The so-called 'Internet Studies' have highlighted the importance of pedagogy declined as a philosophy of education, as a science able to provide, together with other social and cultural sciences, a significant contribution to the understanding of the implications and educational potential of the Net in the age of infosphere. Over the past few years, the so-called 'social networking pedagogy' has emerged as an interdisciplinary approach focusing on curriculum and training. It is a pedagogy that identifies in the interaction that takes place, for example, in social networks ('containers' for communicative interaction) the possibility of developing a learning and training model that not only opens up new scenarios for education of the future through new media but also allows to understand critically the whole contemporary culture. Therefore, starting from the analysis of this scenario and using a theoretical methodology based on mainly hermeneutical-deconstructive and historicaldialectical approaches, the article outlines the possible epistemological framework for the "networking pedagogy' within the Internet studies, and identifies its main issues. The authors highlight how this specific pedagogy develops today as a 'pedagogy of culture' characterized by a positive and optimistic approach to the new media (with particular reference to social networks). After identifying the advantages and disadvantages of the new media, such a pedagogy intends to consider pedagogical issues that teachers and trainers have to focus on and transform into effective educational communication content and tools for the curriculum. The article examines the contributions of the critical pedagogy scholars David Trend and Henry Giroux who can be considered the pioneers of networking pedagogy. The article concludes by highlighting the importance of ethics as a pedagogical practice that, through control, regulation and supervision of communicative interactions in social networks, paves the way for their conscious and educational use.
\end{abstract}

Key words: education; Internet; social networks; new media; training; infosphere

In the contemporary society, the advent of Web 2.0 has profoundly redesigned the complex scenarios of human communication andeducation. The Internet (Net) connects computers and portable devices allowing access and planetary sharing of information which has produced new challenges to pedagogy as a science of

* (C) M. De Martino, S. Kovalenko, G. Tkach, E. Isidori, 2022

The article was submitted on 05.06.2021. The article was accepted on 17.12.2021. 
reflection on the meaning, purpose and content of education. Moreover, the so-called 'infosphere' has changed the way humans communicate and relate to each other.

The term 'infosphere' means a global space in which people exchange information. This is the whole cyberspace (including Internet) and all mass media - both traditional and new media. Scholars use the term 'infosphere' to identify the space in which the physical body, mental extensions and communicative interactions with others (including virtual ones) combine to influence our lives and phantasmatic activities, the human nervous system and, consequently, our knowledge. Experts use this term to highlight how information and its sharing and processing in the Net have changed the relationships between people due to the new communication technologies [11]. 'Analogue' and 'digital' dimensions, on-line and off-line extents of knowledge combine and give rise to a complex interaction between humans and digital interfaces (for instance, in the socalled "Internet of things'.

In this context which mainly concerns the way knowledge is elaborated and shared, pedagogy as a science of knowledge transmission and culture for human improvement plays a fundamental role in understanding scenarios, which is recognized in the Intenet Studies [9]. They examine how the Internet and the technologies that allow its development and implementation created the Homo Educandus as an always-connected being. Information and communication technologies represent technologies of the corporeal and mental type that modify the practices and contexts through which human beings shape themselves and build their knowledge [28. P. 66]. This know-how is increasingly becoming a collective and social knowledge with a networked structure - interconnections, links and references to the internal elements that structure the system itself [18]. For instance, Facebook has become a powerful metaphor of knowledge as a network of interconnected information and knowledge, shared and processed by people in a social and community form [6. P. 53]. Sharing one's knowledge, information and opinions through social networks call the individual to responsibility for one's social self. This phenomenon implies the need for a more pronounced individual and collective consciousness that pedagogy and ethics help to develop [15].

The new anthropology of Homo Technologicus requires an educational look at the Internet and social networks [17]. Homo Communicans and Educandus needs to critically understand the complexity of the social-cultural changes in the digital world. In this virtual reality, people need to find under the various layers that cover them the human values through a new ethical look — more flexible and disenchanted than the Western civilization has elaborated. It is challenging to address any aspect of the contemporary society, culture and education without taking the Internet into account. Many people's lives are so saturated with digital technologies that the distinction between online and offline is no longer able to describe the situation. New generations are not able to speak of the Internet as something external and separate from their lives [4].

However, the impact of the Internet on education is not direct: still more than a half the world population has no direct experience of using the Internet. This 
situation may change in the coming years with the global expansion of mobile telephony, but the problem of the unequal network access remains one of the most urgent today.

The so-called 'Internet pedagogy' or 'Network pedagogy', which is becoming increasingly consolidated as a field of study and research, tries to answer fundamental questions such as: What implications does the Internet have for education and learning, and how can it be transferred in the best possible way into practical training actions for the individual and community? What are the primary forms of online training that have emerged in the last decade? What relationship can we observe between the educational potential of the Internet and its actual use? What are possible advantages and disadvantages of what users share in the Network and learn through it?

For most of the pedagogy scholars, the Net has always been an intrinsically educational tool [24]. They argue that the main characteristics of the Internet coincide to a large extent with the interests, objectives and aims of education. For example, both the Internet and education aim to create knowledge, exchange information and ensure communication. The participatory and community-based nature of many of the Internet's activities is in line with the fundamental characteristics of human learning, in particular 'creating', 'sharing', 'collaborating' and 'analysing'. Thus, given the Internet ability to make these activities possible on a large scale and almost simultaneously, scholars often describe the educational impact of the Internet quite positively, which can be summarized in the four conceptual pillars of Internet pedagogy.

1. The Internet potential to help people learn more freely without the constraints of the 'real' world. It generally reduces local, spatial, temporal and geographical limitations for people who cannot have access to the high-quality learning resources and teaching aids. The Internet provides content at any time and place allowing to learn at an individual pace and style. The Internet overcomes physical and social barriers and is a fundamentally democratic means of communication and interaction. The ability to support interactions and educational experiences with greater freedom and in the context of equity concerning the use of resources is considered a reflection of the intrinsic qualities of the Internet as a "radically democratic space of infinite connectivity" [23. P. 122].

2. The Internet is an agent of the new culture of education based on the principle of collective exploration, play and innovation. The Internet allows learning from 'many to many' rather than from 'one to many' by encouraging social-constructivist training modalities and allowing for the cognitive development of a profoundly social and cultural nature. The Internet allows its users to benefit from extremely information-rich environments, offers an easy access to sources of theoretical and practical knowledge outside their restricted environment. The Internet supports highly effective forms and modes of the 'situated learning' and 'community of practices' distributed digitally and virtually. Therefore, the Internet is considered a powerful tool of learning through authentic activities and interactions between people and broader social environments. 
3. The Internet promotes large-scale connectivity changing the relationship between people and information. The Internet favours forms of creation and consumption of knowledge far from the epistemological hypotheses of both formal and mass education. The online relationships through the reception and sharing of information online have led to a different assessment of the nature of learning. The Net introduces forms of 'collective intelligence' and 'fluid intelligence' from the perspective of connectivism, since online learning is subject to the access and use of information according to personal needs [29. P. 7]. In the connectivist perspective, learning is understood as the ability to connect to nodes and specialized information sources when necessary. In the digital age, learning has become 'situated' and 'in action'; i.e., it has become both social and cognitive. It is 'concrete' rather than 'abstract' and intertwined with judgement, reflection, and exploration.

4. The Internet has radically 'personalised' the way people learn. Therefore, learning and training become much more individualized than in the past. The Internet is associated with the availability of greater autonomy and control by people because it gives more choice not only in the form, characteristics and content but also in where, when and how they learn. In fact, through and in the Net, training becomes an aspect of life that the person can control, because the Internet provides a digital exchange that allows training activities to be carried out simultaneously with with other occupations in daily life. Those who use the Internet often have to possess skills to personally organize and manage their training without having to comply with the rules of the codified education system [10. P. 13].

\section{Philosophy of the 'connectivist' education in the Net}

In the era dominated by the omnipresence of the Net, even the philosophy of education underlines the obsolescence of the behavioural learning model and tends to enhance the connectivist one. Connectivism is a theory of learning developed, among the first scholars, by George Siemens [29]. This theory highlights how, in the era of the omnipresence of new digital technologies, learning is always the result of continuous socialization and communication/critical sharing of the abundant contents present in the Net in the form of information connected in a hypertextual way in a scenario of hyper-connectivity.

The fundamental principle of connectivism is that competence is always the result of connections and sharing of experiences. The principles through which Siemens [29] identified the salient characteristics of learning from the perspective of connectivism, are as follows: diversity of opinion as the base of learning and knowledge; learning as a process of connection between specialized nodes or information sources; non-human devices can facilitate the transmission of learning and knowledge; it is necessary to maintain connections to facilitate continuous learning; the ability to see connections between fields, ideas and concepts is a fundamental skill of a specific competence; assessing knowledge (which must be accurate and up-to-date) is the intent of all activities based on the model of connectivist learning; decision-making is a learning process; choosing what to learn and the meaning of the content you learn through the information you acquire are 
to be considered in the relativistic perspective and as activities of an ever-changing and just-in-time reality; if an answer can be reliable or right today, at a given time or context, it may no longer be so tomorrow due to alterations in the information that affect decisions. Thus, according to connectivism, the fundamental aim of education and training is not to make students memorize information but rather to make them become motivated learners and adopt the philosophy of self-training and continuing education through the digital tools of the Net. For connectivism, knowledge through and in the Net becomes possible if we nurture and maintain such connections [3]. The result is a heuristic and hermeneutic structuring of knowledge that is built by 'discovery' and 'interpretation' through the continuous research and understanding of information and contents within the cyberspace of the Net and not by a simple accumulation of knowledge.

The Internet has challenged the traditional forms of education and training that the nation-states developed in Europe between the $18^{\text {th }}$ and $20^{\text {th }}$ centuries, in particular, the institutionalised and formalised models of schools and universities. The Internet poses a challenge to the monopoly of public education systems and the complex system of interests of the professionals working there. Therefore, the Internet questions the boundary between experts and newcomers, processes of knowledge production and consumption, temporal and spatial limits and conventions of education. As far as teaching is concerned, the Internet is associated with a radically different set of training practices and social relations than in the past. All these changes imply a different philosophy of education and ethics [21. P. 286].

Indeed, the Internet has provoked continuous debate in the education community since the beginning of the new century [20. P. 19]. The Internet has imposed the task of rethinking and reconfiguring the notions of schools and universities so that they can become institutions capable of responding to the real educational needs of the digital age. The task of reinventing schools and universities for the Internet age requires not only to reconsider what is essential to learn but also to rethink learning itself [5] — a new 'anthropology'. The Internet has led to the development of new educational philosophies that have developed teaching methods built around collective creation (rather than individual use and 'consumption') and capable of conveying playful learning based on reflection and enthusiasm to explore. The philosophy that captures, with optimism and positivity, the educational potential of the Web 2.0 has allowed the development of new teaching models open to learning and mastering technologies.

However, the Internet, with its tendency to promote connectivist and democratic modes of learning and training, seems to envisage more radical forms of deinstitutionalization of education that could lead, in a few years, to the perception of traditional educational institutions a redundant and even obsolete. Key concepts such as self-directionality, self-organization, self-education in the pedagogical terminology when linked to the Internet seem to anticipate situations and conditions of total de-schooling of society. All these concepts link the Internet with a general rejection of institutionalized education, especially with what scholars describe as a 'banking model' and considered obsolete due to the accumulation of 
knowledge [12]. Instead, we consider the Internet-based education in the framework of free discussion, open debate, fundamental questions, continuous experimentation and shared knowledge.

Nevertheless, the Internet presents a philosophy of connectivist education that does not destroy but reshapes the traditional school and university, which, at least in the last hundred years, had been the dominant institutionalized educational model. Therefore, philosophically reflecting on the Internet today means discussing the inevitability of educational change, transformation and 'rupture' of contemporary teaching and learning models with those of the $19^{\text {th }}$ and $20^{\text {th }}$ centuries. E-learning represents the most obvious way of using the educational and training potential of the Internet. Until a few years ago, many examples of e-learning consisted basically of providing content in a unidirectional way and, therefore, were nothing more than a replica of traditional forms of distance education. The advent of the Web 2.0 and its subsequent versions has radically changed all this and opened up new perspectives in which the socialization of knowledge plays a decisive role.

\section{Social networks and networking pedagogy}

We can define social network as a 'node' in which each person presents and relates to others, showing situations of everyday life through communication and interpersonal interaction. Each node has a peculiarity; it is formed by the personal characteristics of people who try to join others to improve their qualities, identify themselves and, therefore, build a network with other people in the search for security and pleasure with the intent to satisfy some of their needs and build an identity [14]. In the age of the Internet and digital communication, social network can be defined as a community of people whose members interact and create bonds and relationships through common interests, where ideals are values strengthen the cohesion and purpose for which these networks were created, regardless of geographical distance or time [1]. In the social network, people can interact synchronously or asynchronously, share common values, goals and interests using an electronic/digital support and meeting point. Another characteristic of social networks is what Goffman [14] defined as the presence of rituality. This rituality refers to the concept of digital person that expresses ideas and feelings concerning social, cultural, educational or philosophical principles that inspire and express the personality of the individual, the 'face' of digital person/prósopon.

We can study social networks as systems of interaction and communication in which people develop a code that has to be 'decoded' concerning the context, meaning and value attributed to verbal or non-verbal interactions within the group in the digital modes and according to the roles interpreted by the participants of the group. The social network is a social community built on human interactions and behaviors that make sense when shared among members - they develop the same identity and carry out actions based on values, beliefs and personal meanings, share stories, tasks, interests, spaces or life projects and use a virtual environment for their sense- and meaning-building activities. 
However, there are many prejudices about social networks - they are considered only as platforms such as Facebook, as examples of the drift of communication in its digital and virtual mode in the era of the 'society of entertainment [8]. According to the supporters of this theory, social networks are not real tools for dialogue because they are managed by corporations that exercise control over the content that is shared on these platforms, driving and manipulating the users involved in such a way as to make them passive consumers without a critical spirit. According to these supporters, freedom and gratuitousness (only apparent) of social networks would respond, in reality, to the logic of the market ready to transform into profit the content (even the 'educational' ones) of the communication facilitated by them. We see the system of censorship of violence or the defence of copyright or netiquette of communication in social networks in the perspective of a political-commercial strategy that fully corresponds to the logic of ethics and capitalist culture. According to this logic, everything must be morally and politically correct so as not to upset users and their consciences and, thus, guarantee companies a profit through the sale of advertising. Subject to trivialization of content by the commercial industry, social networks such as Facebook or Instagram would act in the capitalist logic which seeks to make accessible and understandable to the broadest possible audience any content for profit.

In this perspective, social networks and their ethics would reflect the contemporary capitalist culture that turns into a policy of commercialization and commodification with specific rhetorical-textual strategies. The problem of finding a solution - or at least a pedagogical strategy — to develop a critical reflection and an understanding of educational problems in the age of the Net arises from this very point. Challenges of social networks are complicated because they refer to a much broader and more delicate range of problems such as the conciliation between commercialization and education, more specifically - the right to profit of corporations and companies that invest in the development of software and digital tools and the right of people to free, open, critical and not conditioned by lucrative purposes digital tools that improve their implementation.

Concerning the Net in general and social networks in particular, the resolution of this problem should start from the pedagogical strategy based on the 'critical philosophy of media' of Neil Postman [25]. In the age of social networks, media power becomes fundamental. The Net represents the educational but also 'uneducational' scenario of the new society affecting people's growth and development. However, we must distinguish between social networks as a 'product' of corporations that intend to profit from its different uses by 'users' and as 'scheme' - theoretical and applicative model and metaphor of the contemporary education. This last conception of the social network not only refers to a specific educational philosophy that allows to extrinsicate all the extraordinary pedagogical potential of the Net, but also outlines a pedagogical epistemology that reinterprets contemporary pedagogy as a social networking pedagogy.

This pedagogy considers social networks as possible containers of educational content built and shared between all those involved through a continuous exchange 
in the Network. In the philosophy that inspires this educational theory and practice, there is the idea that learning is the result of a critical and conscious re-elaboration by participants in social networks, of input and output experiences that are transmitted by digital technologies. The range of individual, unique and differentiated experiences of participants in interactive and communicative democratic ways allows them to know and understand the social, cultural, political, and economic realities in which the contemporary culture is structured. Social networking is a set of ways in which it is possible to implement free communication through digital tools that allow not only continuous interaction but also strengthening of critical thinking. Social networking can transform any historical, social, political, economic, cultural and pedagogical issues of the world 'outside' social networks into a critical educational content for the learner.

Social networking is the starting point of a specific pedagogy of culture due to its possibility of updating the contents and critically socializing them. Such a pedagogy aims to overcome the distinctions that have always existed and that contemporary pedagogies have not managed to overcome - between contents taught in classrooms and real problems of society. Thus, social networking made possible what David Trend, considered the inspirer of social networking pedagogy, advocated in his book Cultural Pedagogy [30] — the transformative possibilities of the media and the role of teachers as intellectuals who can innovate, following specific paths of conscientization, not only teaching methods but also contents of the school curriculum by bringing urgent problems of society in it.

\section{Social networks, education and values of the contemporary society}

Social networks are just virtual spaces that make networking possible. Moreover, social networks represent only a part of that broader category of the social media that includes other types of the Web 2.0 tools as interactive, social, flexible and potentially able to offer all people the possibility of sharing and producing knowledge. In the pedagogy of networking perspective, social networks are understood as a pedagogy that enhances the educational instances inherent in culture to be useful tools to strengthen the social experience of educators/trainees [16. P. 14]. Between social networks and training/education, there is a relationship of three types: training in social networks - informal learning that is generated by the real experience of social networks through reading, sharing posts, articles, essays on a wide variety of topics, by comparing and accelerating knowledge; learning with social networks - all those resources and potentialities of social networks and their adaptation to the traditional pedagogy and didactics; education related to social networks - development of critical skills for a conscious and responsible use of the 'social resources'.

Castañeda and Gutiérrez [2] have explained these guidelines highlighting at least three main ways of using social networks in education: learning with, through social networks, and learning to live in the world of social networks. Learning with social networks implies the idea that learning takes place within formal and nonformal education, and that social networks provide the student with a creative 
learning environment, facilitate communication between students, between them and teachers, teachers and parents; break the barriers of space and time, in which the teaching and learning process takes place, open windows to the outside world, contextualize it, and promote collaboration, participation, problem-solving, community of practices, metacognition and solidarity. Learning through social networks underlines that learning takes place in informal education which is not 'intentionally' structured - it can take place anywhere, at any time, students can have their profile on the Web and social networks and benefit from social relationships they establish, from collaborations with other people and content sharing; these relationships are spontaneous, and the student acts as a protagonist of learning; the student learns to identify the most useful and truthful information and resources. Learning to live in the world of social networks means that there are many advantages that the Net offers - to learn something every day, exercise critical thinking and freedom of speech, and so on.

In order to transform these advantages into educational tools, social networks should be anchored to values and get out of the mere instrumentality of socialization and uncritical communication that often seems to characterize them as they were created with a mainly recreational function. Only if anchored to the interest and common good, social networks and social media can become instruments of positive and adequate socialization. Social networks have to preserve human values such as friendship, mutual respect, personal and moral integrity and to serve as a platform for the creation, development and transmission of values related to the social environment of the individual in the perspective of intercultural communication in the globalized world. This approach reflects the philosophy that has inspired social networks since their birth. Social networks can act as a community of mutual aid: it is no coincidence that a platform like Facebook has recently added a function that allows the development of mentoring within the groups-communities created. Social networks develop functional virtual social relationships horizontally and transparently reducing the possible pyramidal hierarchy and bureaucratization through direct and immediate access to communication without mediation, with the possibility of the maximum sharing of content and values [7].

This mode of direct and immediate access to the media can certainly provide the basis for democratic communication and education, but there are also risks of educational asymmetries (always necessary in the context of education; otherwise the roles will be confused) [32. P. 40]. Social networks develop a philosophy capable of rethinking the pyramidal models of educational relations, but they must respect the roles of the parties involved.

Thus, social network is an open, cooperative and constructive human system that, through a dynamic exchange (of 'energy' and information), allows the use of the resources its members possess and serves as a platform to enhance their interactions [26]. Social networks are living entities developed through symmetrical, reciprocal, flexible and open relationships. Their members can enter and exit, change their state and function by continuously innovating. Social networks bring together 
heterogeneous individuals belonging to different groups, organizations and institutions with shared interests and objectives oriented towards exchange and the common good. This exchange determines the dynamism of social networks and the production of collective knowledge.

Based on the principles of systemic philosophy, we can say that the Network is greater than the sum of its parts. The same principle applies to the social network all actors participate and are involved in the flexible and consensual distribution, structuring and organization of knowledge in order to achieve the common goal proposed, which generates responsibilities and commitments for the people involved. Thanks to social networks, people satisfy a fundamental need to become a social being. Social networks help to understand the social order, provide us with a safe and supportive space in which, through relationships with others, we integrate and adapt to social practices, receive social recognition and evaluation. This individual balance is projected onto society and, in turn, generates a collective social balance. In the communication in social networks, contacts are charged with feelings and express an emotional load, all fundamental elements to build and maintain groups [22].

Thus, the process of socializing values is broadened and spread by digital communication tools. The social network strengthens solidarity and team spirit, helps to strengthen individual and social identity. The Network becomes a propitious space to exercise the principles of democratic citizenship and participation as an interrelated set of intermediate groups between the individual and the state in civil society [27. P. 139]. The full force of collective action takes shape through civil society. This collective power is responsible for the production of social movements and trends, displacement of group potential, resources and interests for the benefit of all. The Network, therefore, can be considered today the underlying social platform for sharing and strengthening social values of the contemporary society.

\section{The use of social networks in training}

In social networks, all individual and collective energy is invested and directed to generate new beneficial effects for the group. Participation and collaboration between people foster a constructive attitude focused on the common good. Social networks produce individual social action and turn it into collective social action that is more likely to achieve optimal results than that achieved individually. For the construction, evolution and functioning in the interests of socialization, social networks should follow the principles: interests, objectives and aims of social networks should be familiar to the group and not linked to economic profits or commercial interests; social networks should provide freedom concerning control; social networks should create an ecosystem respecting difference and diversity (ideological, cultural, and professional); participation must be conscious and general; communication must be democratic, accessible, horizontal and visible; social network must be open and flexible; interactions with other groups should be encouraged to find solutions using and adapting the experience of others; the existence of the social network should always be in harmony with the community and society in order to develop its values. 
Social networks were born with a social function - to connect people from different backgrounds, cultures and social status, to help them communicate in common interests, to provide spaces for distance education and e-learning [19], for the creation, development and dissemination of human values such as freedom of expression, communication, access to sources and citizenship. The characteristics of social networks represent the potential to develop virtual educational communities capable of teaching and learning as a prerequisite for a more just society. For instance, for the secondary education, social networks can promote educational values and help achieve educational goals effectively: students and teachers should be given an opportunity to have a quality digital literacy that allows the development and continuous updating of the skills, an integrate learning in and out of school, of every available technology to improve learning and communication; of research and critical approach to information. Bearing in mind that social networks are formed by communities that interact and communicate in written and oral form through communication technologies, it is necessary to use methodological strategies which explain meanings and signifiers that can foster the teaching-learning process and the values that are maintained [31].

Therefore, in order for the social network to become an educational space fostered by networking, there should be a commitment among members to accept each other and to negotiate actions to perform a common task and share a cultural capital that allows peer interaction. An educational community is such when it ensures a frank dialogue in the context of always 'complementary' relationships. Community cohesion is the fundamental element of integration that provides the basis for achieving specific objectives. For the social network to become an educational community, it should be governed by a specific educational and social philosophy based on the following values: mutual commitment between the parties - not only to build a climate of trust that guarantees the participation of all its members but also to structure a bond in which people feel an ethical and moral obligation to respect the objectives that the group intends to achieve; shared cultural capital - in order to have equality in discussions and level of knowledge among the members of an educational social network, a joint knowledge base is needed; search for identity - sharing interests, values, desires and developing a feeling of belonging to the group ensure cooperation, collaboration and creation of new knowledge; search for cohesion - when members of the educational community identify and share a joint cultural capital, respect each other's commitments in a peaceful and consensual way; freedom - a social network that aspires to become an educational and didactic resource should be a free educational community supported by common interests without any form of coercion in learning; flexibility and creativity - freedom promotes flexibility, therefore, these two principles ensure creative forms of interactivity.

\section{References}

1. Bueno L. Innovar el procesoeducativo: La construcción de los sujetos. Mexico; 2013.

2. Castañeda L., Gutiérrez I. Redes sociales y otros tejidos online para conectar personas. Aprendizaje con redes sociales. Tejidos educativos para los nuevos entornos; 2010. 
3. Chatti M.A., Jarke M., Quix C. Connectivism: The network metaphor of learning. International Journal of Learning Technology. 2010; 5 (1).

4. Cole R.A. (Ed.). Issues in Web-Based Pedagogy: A Critical Primer. Greenwood Publishing Group; 2000.

5. Collins A., Halverson R. Rethinking Education in the Age of Technology: The Digital Revolution and Schooling in America. Teachers College Press; 2018.

6. Davidovitch N., Belichenko M. Using Facebook in higher education: Exploring effects on social climate: Achievements and satisfaction. International Journal of Higher Education. 2018; 7 (1).

7. Davies J. Facework on Facebook as a new literacy practice. Computers \& Education. 2012; 59 (1).

8. Debord G. Society of the Spectacle. Bread and Circuses Publishing; 2012.

9. Dutton W.H. Internet studies: The foundations of a transformative field. The Oxford Handbook of Internet Studies. Oxfor; 2013.

10. Farmer H., Ramsdale J. Teaching competencies for the online environment. Canadian Journal of Learning and Technology. 2016; 42 (3).

11. Floridi L. Pensare l'infosfera: La filosofia come design concettuale. Raffaello Cortina Editore; 2020.

12. Freire P. Pedagogy of the Oppressed. Routledge; 2013.

13. Aronowitz S., Giroux H. Postmodern Education: Politics, Culture, and Social Criticism. University of Minnesota Press; 1991.

14. Goffman E., Perren H.B.T, Setaro F. La presentación de la persona en la vida cotidiana. Buenos Aires; 1981.

15. Jarvis J. What Would Google Do? Reverse Engineering the Fastest Growing Company in the History of the World. New York; 2011.

16. Kuhn C. Are Students Ready to (Re)-Design Their Personal Learning Environment? The Case of the E-Dynamic. Space; 2017.

17. Longo G.O. La lunga strada di Homo technologicus. Scienza \& Società. $2018 ; 11$.

18. Luckin R. Re-Designing Learning Contexts: Technology-Rich, Learner-Centred Ecologies. Routledge; 2010.

19. Manca S., Ranieri M. Implications of social network sites for teaching and learning. Where we are and where we want to go. Education and Information Technologies. 2017; 22 (2).

20. Marson S.M. Internet ethics for social workers. New Social Worker. 2000; 7.

21. Martin M., Noakes M. Fostering a web 2.0 ethos in a traditional e-learning environment. Electronic Journal of E-Learning. 2012; 10 (3).

22. Menduni E., Nencioni G., Pannozzo M. Social Networks: Facebook, Twitter, YouTube and Others: Social Relations, Aesthetics, Emotions. Milan; 2011.

23. Murphy D. The Architecture of Failure. John Hunt Publishing; 2012.

24. Negroponte N. Being Digital. Milano; 1999.

25. Postman N. Media ecology education. Explorations in Media Ecology. 2006; 5 (1).

26. Reales de Castro E., Bohorquez M.S., Rueda Barrera A.A. Lineamientos conceptuales de las redes sociales: una aproximación de su aplicabilidad a la regulación de la violencia. Lineamientos conceptuales de las redes sociales: una aproximación de su aplicabilidad a la regulación de la violencia; 1995.

27. Requena Santos F. El concepto de red social. Revista española de investigaciones sociológicas. 1989; 48.

28. Seery A. Education, the formation of self and the world of Web 2.0. London Review of Education. 2010; 8 (1).

29. Siemens G. Connectivism: A learning theory for the digital age. International Journal of Instructional Technology and Distance Learning. 2005; 2.

30. Trend D. Cultural Pedagogy: Art, Education, Politics. Greenwood Publishing Group; 1992.

31. Ushakov K.M., Kukso K.N. Advantages of social network analysis in educational research. Russian Education \& Society. 2015; 57 (10).

32. Voivonta T., Avraamidou L. Facebook: A potentially valuable educational tool? Educational Media International. 2018; 55 (1). 


\title{
Образование в условиях развития социальных сетей: между сплоченностью и критической социальной философией новых медиа*
}

\author{
М. Де Мартино므, С.А. Коваленко ${ }^{1}$, Г.Ф. Ткач ${ }^{1}$, Э. Изидори $^{2}$ \\ ${ }^{1}$ Российский университет дружбы народов \\ ул. Миклухо-Маклая, 6, Москва, 117198, Россия \\ ${ }^{2}$ Римский университет Форо Италико \\ пл. Л. Де Босис, 6, 00135, Рим, Италия \\ (email: de-martino-m@rudn.ru; kovalenko-sa@rudn.ru; \\ tkach-gf@rudn.ru; emanuele.isidori@uniroma4.it)
}

\begin{abstract}
Аннотация. Так называемые «исследования Интернета» обозначили важность педагогики как философии образования и как науки, способной наряду с другими социальными и культурологическими дисциплинами внести значительный вклад в понимание последствий развития и образовательного потенциала Сети в современную информациюю эпоху. За последние несколько лет так называемая «социально-сетевая педагогика» оформилась как междисциплинарный подход, сосредоточенный на вопросах обучения и составления учебных планов. Именно педагогика исследует взаимодействие, которое складывается, например, в социальных сетях (как своего рода «контейнерах» коммуникативных практик), определяя возможности развития моделей обучения, которые смогут стать основой новых образовательных сценариев для будущего на основе новых медиа, а также позволяя критически аналазировать всю современную культуру. Основываясь на анализе таких сценариев и опираясь на теоретико-методологические постулаты герменевтически-деконтруктивистского и историко-диалектического подходов, авторы намечают возможные эпистемологические контуры «сетевой педагогики» в контексте интернет исследований, выделяя ее основные тематики. Авторы характеризуют векторы развития данного направления как «педагогики культуры», которой свойственна позитивно-оптимистическая трактовка новых медиа (прежде всего социальных сетей). Отмечая их основные преимущества и ограничения, такая педагогика систематизирует те вопросы обучения, на которых следует сосредоточиться учителям и преподавателям, чтобы разрабатывать эффективный образовательно-коммуникативный контент и новые обучающие инструменты. Авторы оценивают вклад представителей критической педагогики Дэвида Тренда и Генри Жиру как пионеров сетевой педагогики. В заключение подчеркивается важность этики как педагогической практики, которая посредством инструментов контроля, регуляции и наставничества в социально-сетевой коммуникации прокладывает путь для ее осознанного использования в образовательных целях.
\end{abstract}

Ключевые слова: образование; Интернет; социальные сети; новые медиа; обучение; инфосфера

* (C) M. De Martino, S. Kovalenko, G. Tkach, E. Isidori, 2022

The article was submitted on 05.06.2021. The article was accepted on 17.12.2021. 